\title{
Spring and autumn phenology of Bulgarian and German provenances of Common beech (Fagus sylvatica L.) under similar climatic conditions
}

\author{
Krasimira Petkova*, Emil Molle*, Gerhard Huber**, Monika Konnert**, Julian Gaviria** \\ *University of Forestry, 10 Kliment Ochridski blvd., 1797 Sofia, Bulgaria. \\ **1Bayerisches Amt für forstliche Saat- und Pflanzenzucht, Forstamtsplatz 1, 83317 Teisendorf, Germany
}

Corresponding author: Krasimira Petkova, E-mail: kpet@abv.bg

\begin{abstract}
The ongoing climate change creates serious concerns about how tree species will behave under new environmental conditions. Common beech (Fagus sylvatica L.), a main and important tree species in Europe, will also be affected by the coming changes. One possibility to test the adaptability of this tree species is to perform provenance tests, transplanting trees from northern areas to warmer and drier places, and to investigate their behavior over a long period of time (transfer experiments). This work describes such an experiment. A provenance test was established in April 2010 with two-year-old seedlings from 8 provenances of beech -5 from Germany (Bavaria) and 3 from Bulgaria. Our purposes were to determine differences in the manifestation of the spring and autumn phenophases from beech of German and Bulgarian provenances and to seek a relationship between geographical coordinates and altitude of the same provenances and timing of leaf flushing and leaf coloring/shedding. In this experiment we examined leaf unfolding and leaf coloring/shedding in two growing periods (2013 and 2016). We found that the Bulgarian provenances flushed earlier in comparison with the German ones in both growing periods. No statistically significant clustering of the Bulgarian and German provenances during leaf coloring/shedding for the second period of observation was found. Longitude had the most important influence on flushing. A linear relationship between the mean date of leaf coloring and the longitude and latitude was determined, but only for the first growing period (2013), when eastern provenances had later leaf coloring, while more northern provenances had earlier leaf coloring.
\end{abstract}

Keywords: climate change, provenance test, phenological observations, leaf flushing, leaf coloring.

\section{Introduction}

According to the Intergovernmental Panel on Climate Change (IPCC, 2013), the globally averaged combined land and ocean surface temperature has increased by nearly $1^{\circ} \mathrm{C}$ from 1880 to 2012. In the Northern Hemisphere, 1983-2012 was likely the warmest 30-year period of the last 1400 years. The IPCC report concludes that temperature will continue to increase throughout the $21^{\text {st }}$ century in different parts of the world, including Europe.

In Germany the average annual temperature increased by $1^{\circ} \mathrm{C}$ between 1960 and 2000, and the average winter temperature by $2^{\circ} \mathrm{C}$ (Beierkuhnlein et al. 2008). Until the end of the $21^{\text {st }}$ century, the regional climate model ECHAM5-MPIOM (MaxPlanck Institute for Meteorology, Hamburg) predicts a decline in summer precipitation by up to 40 percent for some regions in Germany accompanied by increasing temperatures by up to $3^{\circ} \mathrm{C}$ (Knutzen 2016). For Bavaria an increase in average annual temperature of $1.1-1.8^{\circ} \mathrm{C}$ is predicted until 2050 (compared to the period 1971 - 2000) (Beierkuhnlein et al. 2008; Huber et al. 2014). Serious concerns arise about how tree species will cope with these new environmental conditions created by climate change.

Climate warming may lead to pole and upward migrations of tree species at their expanding edges (Ewald 2012), while increasing drought could severely affect tree growth (Dobbertin 2005) and survival at low latitudinal and altitudinal limits of distribution range (trailing, retreating or rear edge), especially in regions with limited precipitation amounts (Mellert et al. 2016).

Common beech (Fagus sylvatica) is a main and important tree species in Central Europe and Germany. Early tests under controlled conditions show different responses of beech populations from diverse geographic origins (beech provenances) 
to drought, warming and late frost (Thiel et al. 2014; Nielsen and Jørgensen 2003; Kreyling et al. 2012, Harter et al. 2015). Several studies report the negative effects of climate change on beech growth: Beeches from north-eastern Spain show reduced growth starting around 1975. An extreme value was reached in the year 2003 (which was an extremely dry year in many European countries), when growth of mature trees decreased by $49 \%$ compared to growth before 1975 (Jump et al. 2006). Charru et al. (2010) reported that the basal area increment (BAI) of pure and even-aged stands of common beech (Fagus sylvatica) in north-eastern France decreased between 1987 and 2004 by approximately $5 \%$. Beech growth decline due to climate change was also observed in Central and Southern Italy (Rita et al. 2014).

For north-eastern Germany, a study by Scharnweber et al. (2011) showed that even small changes in precipitation regimes can have considerable impact on the growth of beech, whereas van der Maaten (2012) concluded that in future, growth and competitiveness of beech may be negatively affected in some regions in south-western Germany by warmer climate.

These examples attest the negative reaction of beech in Central and Southwest Europe to climate change. Due to its economic and ecological importance throughout Europe, it is essential to improve the resistance of beech forests. To achieve this, investigations on the adaptability of beech under different environmental conditions are needed.

One possibility is to take advantage of the different adaptations of beech provenances by the set-up of provenance tests, transferring beech seedlings from northern areas to warmer and drier places and to investigate their behavior over a long period of time (reciprocal transfer or translocation experiments). This work describes such an experiment.

In collaboration with the University of Forestry in Sofia (Bulgaria), the Bavarian Institute for Forest Seeding and Planting in Teisendorf (Germany) initiated a transplanting or transfer experiment to test the reaction of different beech provenances from Southern Germany to drier and warmer conditions, similar to the ones expected at predicted climate change (Huber et al. 2011), to determine if their adaptation capability would be sufficient to preserve their vitality and productivity without substantial changes. Seeds from eight beech provenances were collected in Bulgaria (3 provenances) and Bavaria (5 provenances) and sowed in the two nurseries Berkovitza (Bulgaria) and Laufen (Bavaria). Differences in germination rate, growth and phenology of the provenances in both nurseries were analyzed. Results for the seedlings under nursery conditions were already reported in Huber et al. (2014). The two-year old seedlings were planted on three field sites in Bulgaria (Vidin, Varbitza and Kipilovo) and two sites in South Germany (Bavaria) (Krainholz, Gickelhausen) in autumn 2009 and spring 2010. The behavior of provenances from South-Germany (Bavaria) under warmer and drier conditions in Bulgaria is of special interest. Therefore, in this paper we present results for phenological traits studied on the field site Varbitza in Bulgaria during two growing seasons - 2013 and 2016, to determine how German provenances are affected by the transfer to warmer and drier conditions.
The goal of the study was to assess the timing of the spring and autumn phenophases for German and Bulgarian beech provenances and their correlation with the origin of the provenances (geographic coordinates and altitude).

\section{Material and Methods}

The experimental site was situated in the Varbitza Forest District in the northeastern part of Bulgaria on the northern slopes of the East Balkan Mountain. The trial was established on a flat terrain facing northwest, at an altitude of $350 \mathrm{~m}$, latitude of $42^{\circ} 57^{\prime} 27^{\prime \prime} \mathrm{N}$ and longitude of $26^{\circ} 37^{\prime} 42^{\prime \prime} \mathrm{E}$. The soil is gray forest soil (Gray luvisols, FAO), mixed sandy and clay, not stony, deep, slightly moist. The parent material is sandstone. The habitat is medium rich to rich. The climate in the region is temperate with an average annual temperature of $11.0^{\circ} \mathrm{C}$ and an annual mean precipitation of $708 \mathrm{~mm}$. The duration of the vegetation period is about 6.5 months.

The test plot was established in April 2010 with two-yearold seedlings from eight beech provenances -5 from Germany (Bavaria) and 3 from Bulgaria (Tab. 1). Seedlings of the provenances Elchingen, Silberbach, Ebersdorf and Mindelzell were produced in the nursery Berkovitza (Bulgaria), whereas seedlings of the provenance Ebrach were provided from Germany. In general, three replicates per provenance with 50 seedlings each in a $2 \times 1 \mathrm{~m}$ scheme were planted (von Wühlisch et al. 1998). Due to the low number of seedlings of the provenances Elchingen and Peshtera the number of replicates was reduced to one (Elchingen) and respectively two (Peshtera). In this experiment we examined leaf unfolding (LU) on remaining seedlings at the beginning of the fourth (LU 4 - 2013) and seventh (LU 7-2016) growing period. The observations include 23 to 123 saplings per provenance (Tab. 1). LU was estimated using a six point scale developed by Forstreuter (2002) (Tab. 2). On the same trees leaf coloring/leaf shedding was observed in autumn 2013 (LC 4) and 2016 (LC 7) using a five point scale (Forstreuter 2002) (Tab. 2). Air temperature and relative air humidity were measured using a data logger (VOLTCRAFT USB humidity-temp. logger DL-120 TH). The sensor was installed in $1.5 \mathrm{~m}$ height above the ground using a pole located in an open area near to the studied plot. The sensor was protected by a white plastic shelter to prevent any exposure to rain or to direct sunlight. Data were recorded hourly starting from 13 April 2010, the date of plot installation, until present. Relevant for this study were the average diurnal air temperature and the air humidity between March and November 2013 and 2016 (Fig. 1).

Two types of analyses were performed:

1.) A comparison of means, to test for differences between the provenances using one-way ANOVAs. TukeyHSD were done as post-hoc-tests to determine which provenances differed from each other.

2.) Regression analyses, to relate the phenophases leaf unfolding and leaf coloring/shedding to latitude, longitude and altitude, using linear regression models. 
Table 1

Origin of provenances and mean values ( \pm standard deviation) of phenological phases ( $L U=$ leaf unfolding; $L C=$ leaf coloring) in the fourth (2013) and seventh (2016) growing period for each provenance.

\begin{tabular}{|c|c|c|c|c|c|c|c|c|c|c|c|c|c|c|}
\hline Country & ovenance & ngitude & Latitude & MAT & $\mathrm{mm}$ & Altitude & mean value & $\begin{array}{l}4 \\
\text { observed } \\
\text { plants }\end{array}$ & mean value & $\begin{array}{l}7 \\
\text { observed } \\
\text { plants }\end{array}$ & mean value & $\begin{array}{l}4 \\
\text { observed } \\
\text { plants }\end{array}$ & mean value & $\begin{array}{l}7 \\
\text { observed } \\
\text { plants }\end{array}$ \\
\hline rmany & Elchingen (Elch) & $10^{\circ} 03^{\prime}$ & $48^{\circ} 27^{\prime} 21^{\prime \prime}$ & 8.1 & 705 & 560 & $2.71 \pm 0.77$ & 23 & 3.24 & 23 & $3.00 \pm 0.30$ & 23 & .42 & 23 \\
\hline many & Silberbach (S) & $12^{\circ} 11^{\prime} 00^{\prime \prime}$ & $50^{\circ} 08^{\prime} 00^{\prime \prime}$ & 6.0 & 700 & 611 & .70 & 00 & & . & & 89 & 38 & 77 \\
\hline rmany & Ebersdorf(E) & $11^{\circ} 19^{\prime} 41^{\prime \prime}$ & $50^{\circ} 30^{\prime} 15$ & 6.5 & 900 & 650 & $2.97 \pm 0.71$ & 79 & $3.54 \pm 0.75$ & 123 & $2.98 \pm 0.28$ & 79 & $2.73 \pm 0.38$ & 123 \\
\hline rmany & Mindelzell (M) & $10^{\circ} 25^{\prime} 23^{\prime \prime}$ & $48^{\circ} 13^{\prime} 0$ & 1.0 & 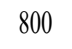 & 565 & \pm 0.75 & 74 & & 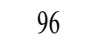 & 0.28 & 1 & 0.34 & (0) \\
\hline rmany & Ebrach (Ebr) & $10^{\circ} 29^{\prime} 18^{\prime \prime}$ & & 8.0 & 800 & 344 & $2.66 \pm 0.76$ & 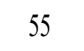 & .78 & 76 & .24 & 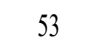 & 0.37 & 76 \\
\hline Bulgaria & $\mathrm{P}$ & $24^{0} 2$ & $41^{\circ} 58^{\prime} 2$ & 7.0 & 960 & 1300 & $2.99 \pm$ & t. & $57 \pm 0.68$ & 54 & & 42 & $1 \pm 0.36$ & 54 \\
\hline Bulgaria & Berkovitza (B) & $23^{\circ} 09^{\prime} 87^{\prime \prime}$ & $43^{\circ} 21^{\prime} 21^{\prime \prime}$ & 10.4 & 825 & 50 & $3.53 \pm 0.61$ & 76 & $3.92 \pm 0.63$ & 115 & $2.88 \pm 0.32$ & 76 & $2.88 \pm 0.36$ & 115 \\
\hline Bulgaria & Petrohan (P) & $23^{\circ} 14^{\prime} 20^{\prime \prime}$ & $43^{\circ} 15^{\prime} 18^{\prime \prime}$ & 10.4 & 1004 & 800 & $3.21 \pm 0.66$ & 62 & $3.72 \pm 0.74$ & 71 & $2.85 \pm 0.29$ & Jo & $2.80 \pm 0.37$ & 11 \\
\hline
\end{tabular}

Table 2

Scoring scales for phenological stages (Forstreuter et al. 2002)

\begin{tabular}{ccc} 
Score & Leaf flushing (LU) & Leaf coloring / leaf shedding (LC) \\
\hline 0 & Dormant winterbud & $100 \%$ summer stage (green leaves) \\
1 & Buds swollen and elongated & $1-5 \%$ of the leaves are colored or shed \\
2 & Bud-burst first green is visible) & $6-49 \%$ of the leaves are colored or shed \\
3 & Leaves begin to appear & $50-99 \%$ of the leaves are colored or shed \\
4 & Leaves are not completely unfolded & $100 \%$ of the leaves are colored or shed \\
5 & Leaves are fully unfolded &
\end{tabular}
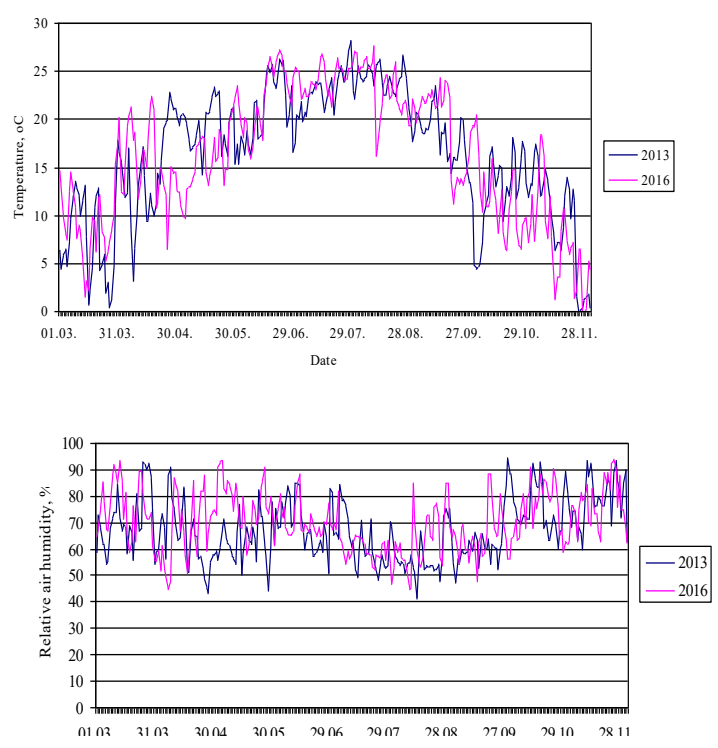

Fig. 1

Air temperature and relative air humidity in Varbitza from March to November for the years 2013 and 2016
Analysis of the data was carried out with the R package stats ( $R$ Core Team, 2014) and the models were visualized with the graphical functions in the R package ggplot2 (Wickham, 2009).

\section{Results}

\section{Leaf flushing}

The average value of leaf flushing (LU) ranged from 2.66 (Ebrach) to 3.53 (Berkovitza) in 2013 and from 3.14 (Mindelzell) to 3.92 (Berkovitza) in 2016 (Table 1). In both growing periods the highest values were reached by the Bulgarian provenances Berkovitza and Petrohan (these provenances unfolded their leaves earliest), whereas the lowest values were reached by the German provenances Ebrach (2013) and Mindelzell (2016). The flushing progress for the tested provenances in 2013 and 2016 is presented in Fig. 2. In 2013 observations for leaf unfolding were carried out on seven dates, between 19.04. (109th Julian day) and 07.05. (127th Julian day), when all seedlings reached stage 5 . The average diurnal temperature for this period varied between 9.9 and $22.9^{\circ} \mathrm{C}$ (Fig.1). The lowest temperature during this period was $5.4^{\circ} \mathrm{C}\left(23.04\right.$, at 5 am), the highest one $29.1^{\circ} \mathrm{C}$ (28.04., at $3 \mathrm{pm}$ ).

In 2016 the flushing of all provenances started earlier. Six observations were performed starting from 06.04. (97th Julian day) to 05.05. (126th Julian day). During this period the mean diurnal temperature varied between 6.5 and $22.4^{\circ} \mathrm{C}$ (Fig. 1). The lowest temperature was registered the 22.04. at 5 am with 4.3 ${ }^{\circ} \mathrm{C}$, the highest value the 18.04 . at $3 \mathrm{pm}$ with $32.2^{\circ} \mathrm{C}$. In both years no frost events occurred during the leaf flushing period.

The Bulgarian provenances Berkovitza and Petrohan started flushing earliest in both growing periods (Fig. 2). The German provenances Ebrach, Elchingen and Mindelzell started later, changed their ranking partially across the observation period, but remained behind the two Bulgarian provenances Berkovitza and Petrohan. The third Bulgarian provenance Peshtera, which comes from high elevation (1300 m), had an 

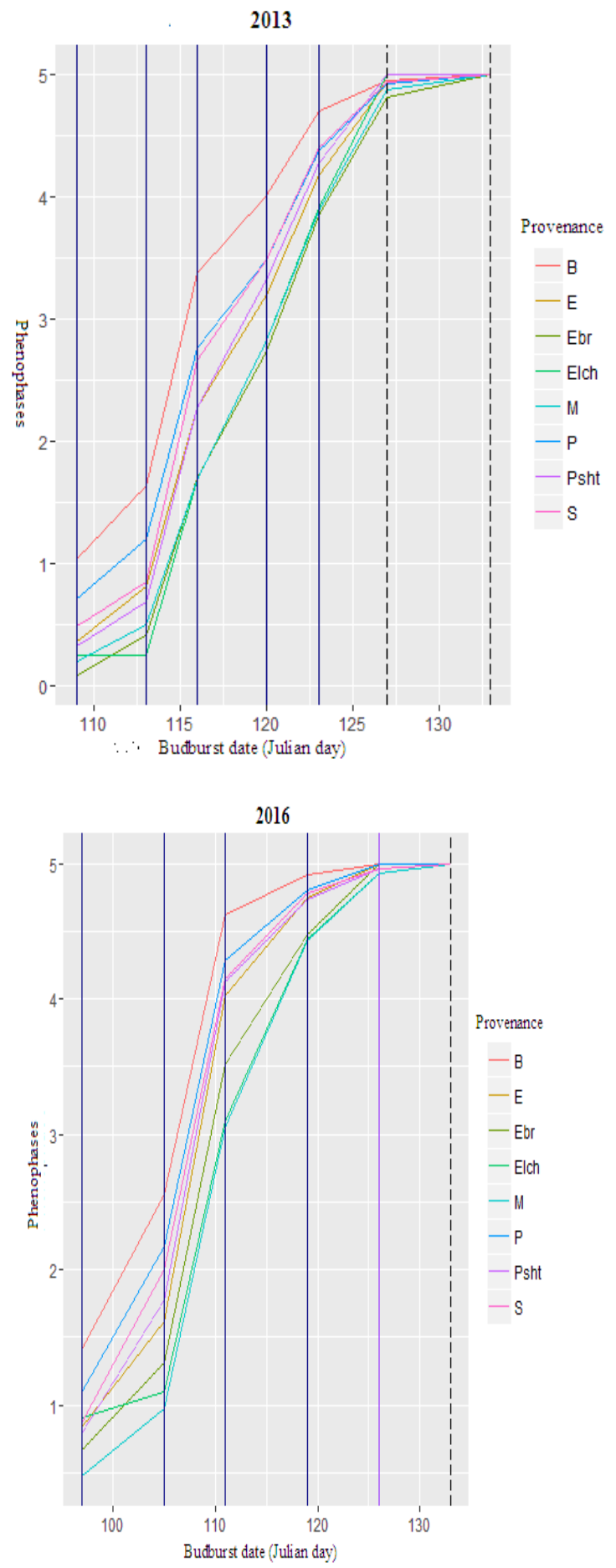

Fig. 2.

Leaf unfolding progress in 2013 and 2016 for the eight beech provenances (B: Berkovitza, E: Ebersdorf, Ebr: Ebrach, Elch: Elchingen, M: Mindelzell, P: Petrohan, Psht: Peshtera, S: Silberbach). Colors and form of vertical lines correspond to the following levels of significance for differences between provenances: ${ }^{* * *}-0.001$ (darkblue continuous line); ${ }^{* *}-0.01$ (purple, continuous line), not significant (black, long-dashed line). intermediate position between Bulgarian and German provenances. Excepting the last two observations in 2013 and the last observation in 2016, differences in leaf unfolding between provenances were significant at different significance levels (Fig. 2).

The Tukey HSD test was applied to all phenophases and all data for which differences between the provenances were statistically significant at least at the $5 \%$ level. The test brought up different provenance groups with different levels of development (Fig. 3 and 4). For the 109th Julian day in 2013, the earliest flushers were the Bulgarian provenances Berkovitza and Petrohan, followed by the German provenances Silberbach and Ebersdorf and the Bulgarian provenance Peshtera. The latest flusher was the German provenance Ebrach. However, the provenance Berkovitza was the earliest flusher for the entire observation period (Fig. 3).

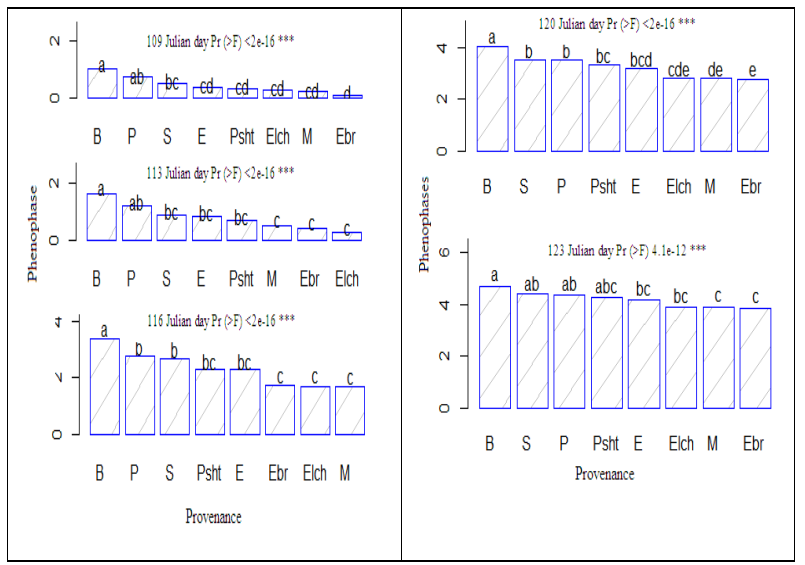

Fig. 3

HSD of Tukey for the leaf flushing in 2013

The provenance Petrohan ranked second, but was gradually replaced throughout the growing season by the German provenance Silberbach, which accelerated its development and ranked second at the end of the observations. The three German provenances Ebrach, Mindelzell and Elchingen were always the latest to flush; however, their ranking changed througout the observation period.

In 2016 the pattern of flushing was in great part similar to 2013. The provenance Berkovitza, followed by Petrohan, were the earliest flushers also in this observation period (Fig. 4). The German provenances Mindelzell followed by Elchingen and Ebrach flushed latest. A relatively late flusher was also the Bulgarian provenance Peshtera, with the third (97th Julian day) and the fifth rank (111th Julian day).

\section{Leaf coloring/Leaf shedding}

The average value of leaf coloring in individual provenances ranged from 2.85 (Petrohan) to 3.00 (Elchingen) for the first period of the study and 2.71 (Elchingen) to 2.88 (Berkovitza) for 


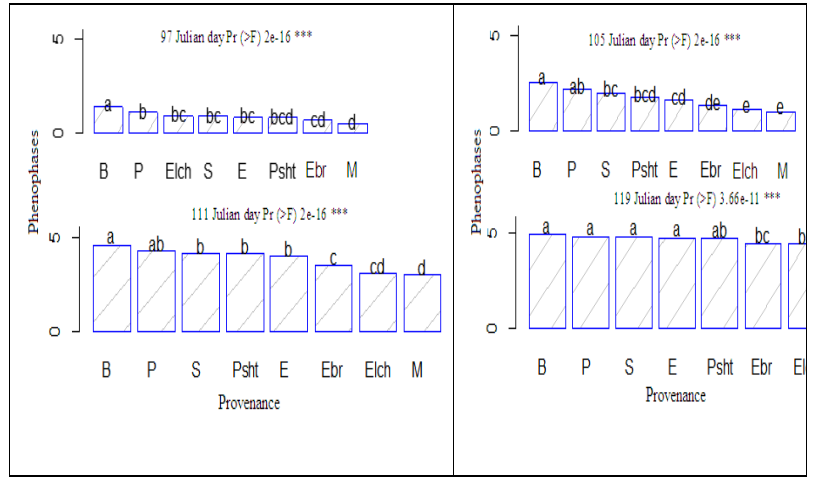

Fig. 4

HSD of Tukey for the leaf flushing in 2016

the second period (Table 1). The highest average value corresponded to the provenance with the longest growing period. Thus, there was no clear correlation between the provenance and the termination of the growing period: While in 2013 the German provenance Elchingen had the highest average value, in 2016 it was the Bulgarian provenance Berkovitza. In 2013 the Bulgarian provenance Petrohan had the lowest average value, while in 2016 it was the German provenance Elchingen.

Data on leaf coloring development in 2013 and 2016 are presented for the different provenances in Fig. 5. In 2013, the main leaf coloring/shedding phenophases were reported twelve times from 10.09. (253rd Julian day) to 03.12. (337th Julian day) and in 2016 only seven times from 19.09. (263rd Julian day) to 23.11. (328th Julian day). The average diurnal temperature for the periods ranged from -0.4 to $23.5^{\circ} \mathrm{C}$ in 2013 and from 1.2 to $22.1^{\circ} \mathrm{C}$ in 2016 (Fig. 1).

Leaf coloring behavior differed between 2013 and 2016 (Fig. 5). In 2013 half of the records (6) were significant, whereas in 2016 only the first two observations (263rd Julian day and 277th Julian day) records out of seven show significant levels of differentiation. The strongest differences (highest level of significance $p<0.001$ ) were observed between provenances at the 253rd Julian day (first observation date in 2013 when five distinct groups were distinguished, see Fig. 6). Provenance Ebrach reached on this day phenophase 1.5 (a), followed by the German provenances Ebersdorf (ab), Mindelzell (abc), Silberbach, Elchingen and Petrohan (bc). At the same date, the Bulgarian provenances Berkovitza and Peshtera (c) had not reached phenophase 1 (Fig. 5). At the 260th Julian day three groups of provenance at $p<0.01$ were differentiated (Fig. 6). The German provenance Ebrach formed the first group (a); in the second group the German provenances Ebersdorf. Elchingen and Mindelzell as well as the Bulgarian provenance Petrohan were included (ab). The third group was composed by the Bulgarian provenances Peshtera and Berkovitza and the German provenance Silberbach (b). At the 267th and 281st Julian days the provenances were distributed mainly in 2 and 3 groups (Fig. 6) at the same level of significance $(p<0.01)$, whereas at later dates no statistically significant differences between provenances were observed. The provenance Ebrach had the most prolonged period of leaf coloring that began first and ended last. The first freezing temperatures in 2013 were

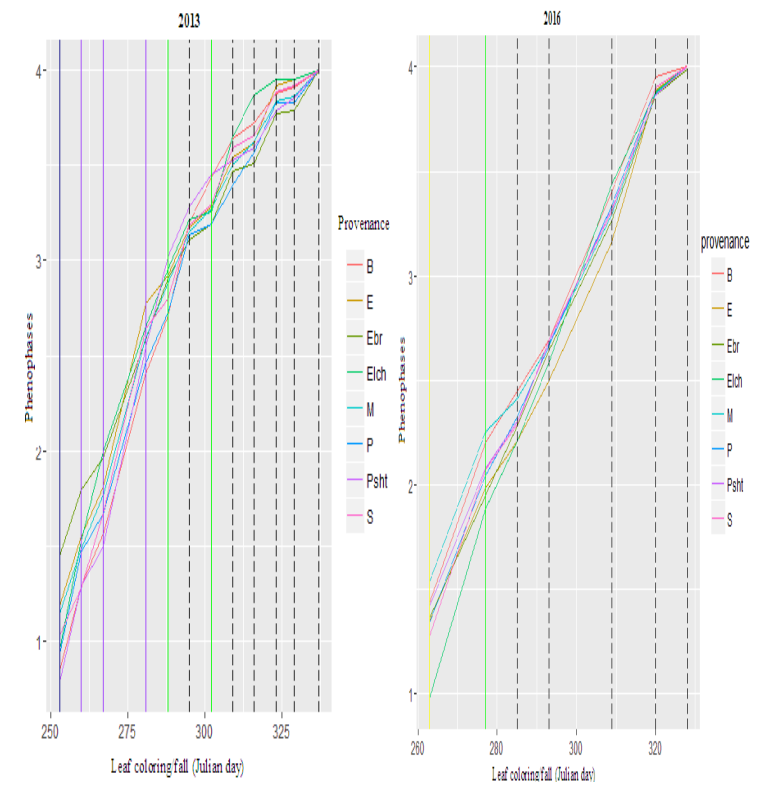

Fig. 5

Development of leaf coloring/shedding of beech provenances in 2013 and 2016. B: Berkovitza, E: Ebersdorf, Ebr: Ebrach, Elch: Elchingen, M: Mindelzell, P: Petrohan, Psht: Peshtera, S: Silberbach). Colors and form of vertical lines correspond to the following levels of significance for differences between provenances: ${ }^{* * *}-0.001$ (darkblue continuous line); ${ }^{* *}-0.01$ (purple, continuous line), * -0.05 (green, continuous line), - 0.1 (yellow, continuous line) not significant (black, long-dashed line).

recorded the 05.10. (278th Julian day). From that date on, the leaf coloring phenophase of most of the German provenances and the mountain Bulgarian provenance Peshtera was above 2.5 and 3 respectively. Only the Bulgarian provenances Berkovitza and Petrohan did not reach the phenophase 2.5. Complete leaf coloring/shedding of all origins was only reached the 03.12.2013, probably due to a stable cold snap with temperatures below $0^{\circ} \mathrm{C}$ that started the 23.11.2013.

In 2016, there was no clear grouping of German and Bulgarian provenances regarding the leaf coloring/shedding behaviour. At the first observation (263rd Julian day), the provenance Mindelzell clearly stood out (a, Fig. 7), with an average value of 1.5, whereas the provenance Elchingen reached only phenophase 1 (b, Fig. 7) ( $p<0.1$, see also Fig. 5). The other German and Bulgarian provenances formed only one group (ab, Fig. 7). At the second observation (277th Julian day), provenances showed significantly different phenophases (Fig. 5). However, the post-hoc test could not distinguish between the provenances (Fig. 7). Although the leaf coloring of the German provenance Ebersdorf developed slowest and of the Bulgarian provenance Berkovitza developed fastest, after this date the differences in leaf coloring between the provenances were not significant (Fig. 5). 


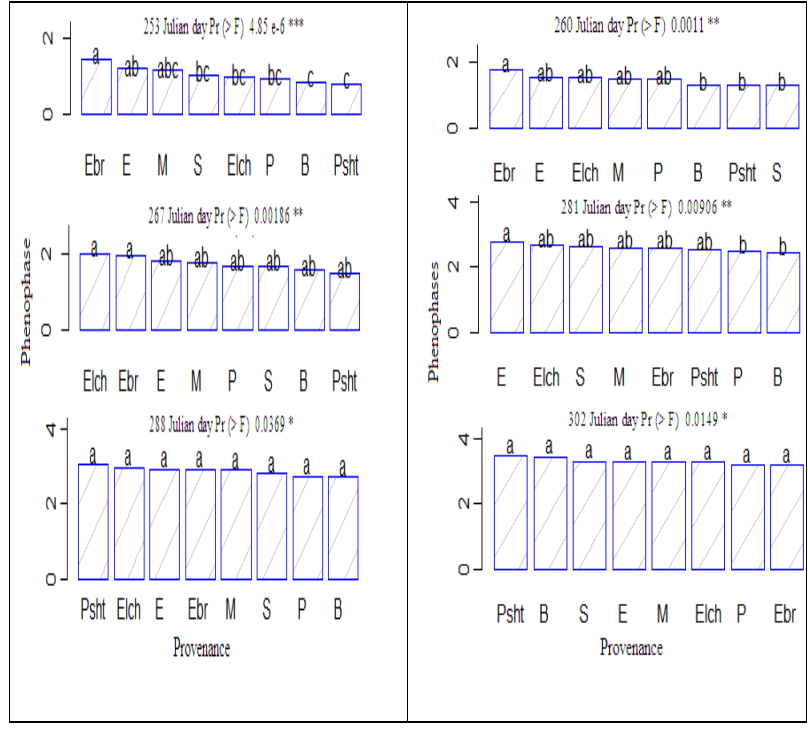

Fig. 6

HSD of Tukey for the leaf coloring in 2013
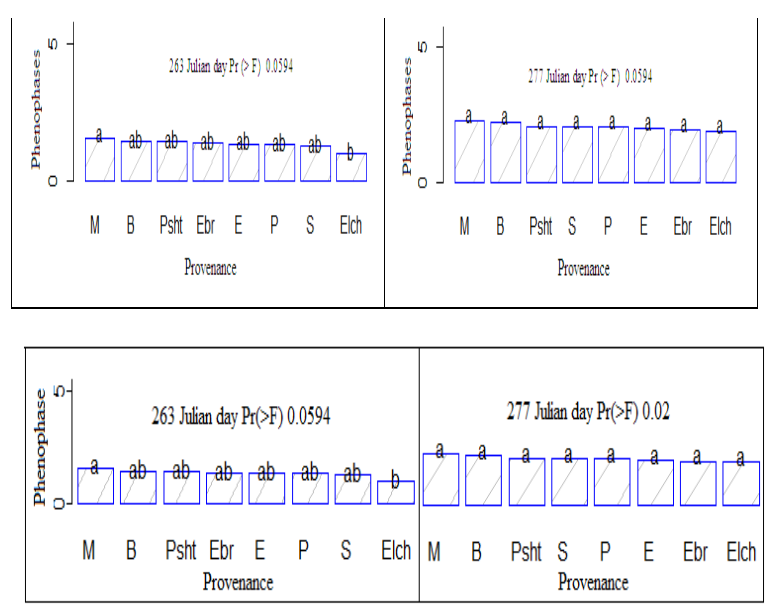

Fig. 7

HSD of Tukey for the leaf coloring in 2016

\section{Relationship between phenophases and geogra- phical coordinates}

The regression analysis showed a statistically significant relationship between the average date of leaf flushing and the longitude of the provenances origin in the fourth growing period $\left(2013, r^{2}=0.569 p=0.03\right)$ and the seventh growing period $\left(2016, r^{2}=0.532 p=0.04\right)$ (Fig. 8). The dependence was directly proportional i.e. with increasing longitude (more Eastern provenances) leaf flushing started earlier. The Bulgarian provenances in both studied vegetation periods flushed earlier than the German ones and two clearly distinct groups - Bulgarian and German provenances - stood out.

No significant relationship between altitude and the degree of shedding was found for any of the growing periods. A linear relationship between the mean date of leaf coloring and the longitude and latitude was detected only in 2013, but with high statistical significance $\left(r^{2}=0.715 p=0.01\right.$ for longitude

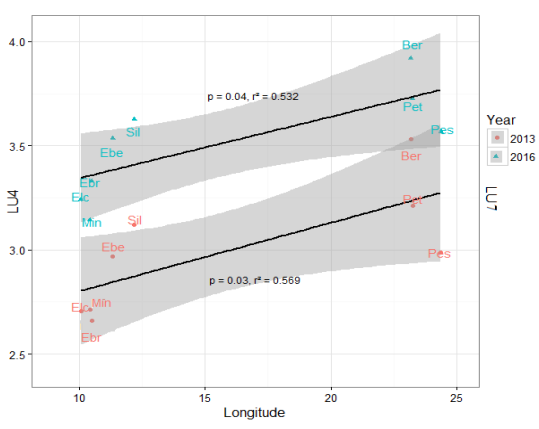

Fig. 8

Relationship between the average date of the leaf flushing and the longitude

and $r^{2}=0.609 p=0.02$ for latitude) (Fig. 9). While leaf coloring was inversely proportional with longitude, the situation was opposite for latitude. In other words, more Eastern and Southern provenances had later leaf coloring. The groups of Bulgarian and German provenances were clearly distinct in both cases.

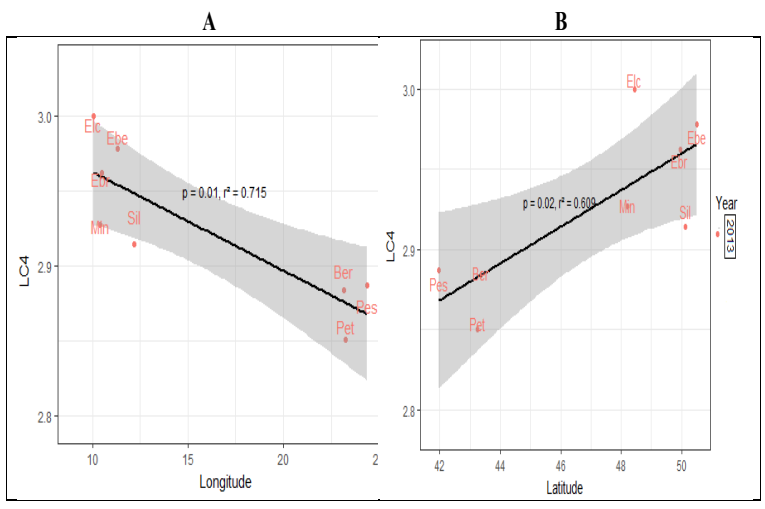

Fig. 9

Relationship between average date of leaf coloring and longitude (A) and latitude (B)

\section{Discussion}

Under climate change silviculture is confronted with the question whether the phenotypical adaptive capacity of local provenances is sufficient to ensure survival and productivity in the future or if supportive actions are necessary. This study tested via a reciprocal transfer experiment the potential of beech provenances from Southern Germany to adapt to novel climatic conditions already existing in Bulgaria. The cultivation under warmer and drier conditions virtually pre-empts the expected climate changes. The study focused on spring and autumn 
vegetative phenology, generally considered important fitnessrelated traits.

The first investigation of the studied German and Bulgarian provenances was made on seedlings under nursery conditions in Bulgaria and Bavaria (Huber et al. 2014). Results show that in the propagation phase under relatively optimal conditions the German provenances were able to keep up with the Bulgarian ones at the warmer nursery site in Berkovitza/ Bulgaria. Here we present the first observations in the field on the Varbitza plot during two growing periods. Varbitza and the nursery Berkovitza have similar climate: Mean annual temperature is $11.0^{\circ} \mathrm{C}$ and $10.4^{\circ} \mathrm{C}$, and mean annual precipitation is 708 and $825 \mathrm{~mm}$ for Varbitza and Berkovitza, respectively. Under these conditions Bulgarian provenances flushed earlier compared to the German ones on both sites. An earlier flushing of the local beech provenances compared with provenances from other regions was reported also by Ballian et al. (2015) in phenological observations of 22 European beech provenances in a provenance test in Bosnia and Herzegovina. Earlier flushing of a Bulgarian provenance (Gotse Delchev) that was moved about 10 degrees to the north is documented also by Eilmann et al. (2014) in an experimental trial near Wageningen (Netherlands). Similar results have been reported by Chmura and Rozkowski, (2002), Višnjić and Dohrenbusch (2004) and Gömöry and Paule (2011). The provenance Gotse Delchev is included also in a provenance trial of 32 European beech populations in the southwestern part of the natural range of beech in northern Spain, at a similar latitude as the mother stand. Here it was recorded as one of the earliest flushers (Robson et al. 2013). Genetic control of phenological traits was confirmed for beech by Robson et al. (2011), by extensive observations of beech provenance tests from all over Europe. In summary, phenological behavior is preserved when moving provenances to different locations. Together with our results, these findings support that leaf flushing of beech is determined genetically and less influenced by environmental factors. The Bulgarian mountain provenance Peshtera flushed slightly later in both observation periods (2013 and 2016) in the Varbitsa provenance test, as well as in the nursery in Berkovitsa (Huber et al. 2014), occupying an intermediate position between the Bulgarian and German provenances (Fig. 2). It can be expected that seedlings of high-altitude provenances transplanted to lower altitudes benefit from the benignant climate and flush earlier. However, the fact that our results do not show an earlier flushing of the provenance Peshtera again supports the notion that leaf flushing is controlled genetically and less influenced by external factors. As discussed above, the same applies to the German provenances, which did not benefit from the warmer climate in Varbitza.

The role of the geographical origin on leaf flushing of beech provenances has been studied by many authors (von Wühlisch et al. 1995; Chmura and Rozkowski 2002; Jazbec et al. 2007; Robson et al. 2011; Gömöry and Paule 2011). Von Wühlisch et al. (1995) examined samples from 158 beech stands from most parts of Europe and concluded that with increasing longitude and altitude and decreasing latitude beech provenances have lower heat demands for bud-burst. Out of the mentioned parameters longitude had the strongest effect.
Chmura and Rozkowski (2002) obtained similar results for 38 beech provenances from Poland. The territory of Poland is situated in the transition zone between a maritime climate in the west and a continental climate in the east. The eastern populations started growing and culminated the growing process earlier than western provenances, and the authors concluded that this may reflect their adaptation to continental conditions with shorter intermediate seasons (spring and autumn). For a test with 36 European beech provenances in Croatia Jazbec et al. (2007) reported that western and northern provenances flushed later compared to eastern and southern ones. Robson et al. (2011) summarized the results of twenty annual phenological observations in thirteen experimental plantations throughout Europe. They asserted a general trend for provenances from the south-east of Europe in Mediterranean and warmcontinental regions to flush earlier compared with late-flushing provenances from the north and west of Europe, where Oceanic influences are strong. Gömöry and Paule (2011) based their studies on phenological observations on 32 European beech provenances in Slovakia. They also noticed that provenances from the eastern part of the natural distribution range and from lower elevations tended to flush earlier. In our study we come to the same result: the Bulgarian provenances from the southeastern part of the natural distribution range of European beech flushed earlier than the German ones originating from Central Europe. In summary, southeastern provenances tend to flush earlier than their northwestern counterparts, a mechanism that is endogenous regulated. When transferring southeastern provenances to northwestern sites, they will flush earlier. However, this may represent a risk as due to the early flushing they are more prone to damage through early frost events (Robson et al. 2011; Gömöry and Paule 2011).

With regard to autumn phenophases, it is noticeable that in 2016 the onset of the leaf coloring/shedding was about 10 days later than in 2013. On the one hand, the warmer August and September of 2016 compared to those of 2013 may be responsible for this. Higher temperatures in August and September are a prerequisite for a delay in autumn leaf coloring, as indicated in the studies of Estrella and Menzel (2006), Čufar et al. (2012) and Anev and Tzvetkova (2012). On the other hand, the monthly precipitation in August 2016 was 2.5 times higher compared to August 2013 (78.9 mm vs $30.3 \mathrm{~mm}$ ). It is likely that this may have improved soil moisture, and together with the high temperatures have helped to prolong the functional activity of the leaves.

For the first observation period in 2013, a significant positive relation between average leaf coloring date and latitude, and a significant negative relationship between leaf coloring and longitude were found (Fig. 9). In contrast, these relations were not significant in 2016. This may have been a result of the warmer and wetter conditions in 2016 compared to 2013, which led to a delay in the onset of the autumn phenophases of all provenances and to approximately the same development. Additionally, Peñuelas et al. (2002); Gordo and Sanz (2009) and Menzel et al. (2006) found that the change in the dates of leaf senescence and fall in the phenological records are slower, more heterogeneous and less consistent than those 
for leaf unfolding. Our results from 2016 support this statement.

To summarize our results, the evaluation of the spring and autumn phenophases of the investigated German and Bulgarian provenances showed that the Bulgarian provenances flushed earlier in both observation periods, which may lead to a higher susceptibility to late frost damage. In 2013, a correlation between the average leaf coloring date and geographic coordinates was found, while in 2016, the leaf flushing of all studied provenances was earlier and the onset of the leaf coloring later due to the specific climatic conditions during the year.

With increasing temperature and periods of drought there is an increasing demand from forestry for provenances from warmer southern regions. The transfer of forest reproductive material or assisted migration of heat- and drought-adapted provenances from the southern range margins in particular is proposed as a tool for climate adaption. Phenological studies are crucial when making decisions about transfer of southeasthern beech provenances adapted to warmer and drier climates to more northwestern sites. On the one hand, southeasthern provenances may have a longer growing period due to earlier flushing and later growth culmination, which could increase their growth rates. On the other hand, exactly this characteristic makes them very susceptible to frost damage. Gömöry and Paule (2011) showed that late-frost damage is almost entirely determined by the bud burst date. Late frost will remain an important factor in Central Europe, even under climate change, with negative effects on growth rates. A similar assertion was made by Robson et al. (2011) regarding the transfer of beech provenances from Southeast Europe to the northwest. Therefore beech seed transfer from Southern to Central Europe has to be seen critically at least at the moment and not as an positive option for adaptation of beech forests to climate change. Otherwise beech provenances from Central Europe have not changes their phenology under the warmer and drier conditions in Bulgaria. Thus they will not benefit from longer growing periods since their phenology seems to be endogenously regulated, but will be more resistant to late frost events. Together with the good performance of German provenances in Bulgaria until now (data not yet published) it seems that beech provenances from Southern Germany will be able to adapt to warmer and more drier conditions and perhaps assisted migration from Southern to Northern Europe over long distances will not be necessary. However, it must be stressed that at this stage of the experiment it is too early to give reliable recommendations on beech provenance use or seed transfer for adaptation of forests to climate change. Data on survival and growth of the studied provenances are actually subject of another study and in combination with this study will give an answer to this question. If considered necessary any transfer of provenances should be well documented and made under consideration of the scientific knowledge gained from phenological studies, to prevent massive losses (Konnert et al. 2015).

\section{Acknowledgement}

The presented results were part of a bilateral Bavarian - Bulgarian project on "Transfer experiments with beech (Fagus sylvatica) and silver fir (Abies alba) to test adaptedness in a changing climate" financed by the Bavarian Ministry of Food, Agriculture and Forestry (StMELF).

\section{References}

Anev S, Tzvetkova N (2012) Effect of temperature regime on phenological phases and duration of vegetation period of young beech (Fagus sylvatica L.) stands in the West Balkan mountain. In: M. Morell (Editor), Fifth International Conference BALWOIS 2012 on Water, Climate and Environment, Ohrid, FYROM, on-line http://balwois.com/k9proceeding/254-effect-of-meteorological-factors-on-phenological-phases-and-duration-of-vegetation-period-of-young-beech-fagus-sylvatica-l-stands-in-the-west-balkanmountain

Beierkuhnlein C, Foken T (2008) Klimawandel in Bayern.Auswirkungen und Anpassungsmöglichkeiten. Bayreuther Forum ökologie, 113.

Ballian D, Jukić B, Balić B, Kajba D, von Wühlisch G (2015) Phenological variability of European beech (Fagus sylvatica L.) in the International provenance trial. Šumarski list, 11-12: 521-533.

Charru M, Seynave I, Morneau F, Bontemps JD (2010) Recent changes in forest productivity: an analysis of national forest inventory data for common beech (Fagus sylvatica L.) in north-eastern France. Forest Ecology and Management, 260: 864-874. https://doi.org/10.1016/j.foreco.2010.06.005

Chmura DJ, Rozkowski R (2002): Variability of Beech Provenances in Spring and Autumn Phenology, Silvae Genetica 51:123-127.

Čufar K, De Luis M, Angel Saz M, Črepinšek Z, Kajfež-Bogataj L (2012) Temporal shifts in leaf phenology of beech (Fagus sylvatica) depend on elevation, Trees-Structure and Function , 26:, 1091-1100. https://doi.org/10.1007/s00468-012-0686-7

Dobbertin M (2005) Tree growth as indicator of tree vitality and of tree reaction to environmental stress: a review. Eur J Forest Res 124: 319-333. https://doi.org/10.1007/s10342-005-0085-3

Eilmann B, Sterck F, Wegner L, de Vries SM, von Arx G, Mohren GM, den Ouden J, Sass-Klaassen U (2014) Wood structural differences between northern and southern beech provenances growing at a moderate site. Tree Physiol. 34 :882-893. https://doi.org/10.1093/treephys/tpu069

Estrella N, Menzel A (2006) Responses of leaf colouring in four deciduous tree species to climate and weather in Germany, Climate Research, 32: 253-267. https://doi.org/10.3354/cr032253

Ewald J (2012) Vegetation databases provide a close-up on altitudinal tree species distribution in the Bavarian Alps. Biodiv Ecol 4: 41-48. https://doi.org/10.7809/b-e.00058

Forstreuter M (2002) Auswirkungen globaler Klimaänderungen auf das Wachstum und den Gaswechsel $(\mathrm{CO} 2 / \mathrm{H} 2 \mathrm{O})$ von Rotbuchenbeständen (Fagus sylvatica L.). Landschaftsentwicklung und Umweltforschung, $119 \mathrm{pp}$

Gömöry D, Paule L (2011) Trade-off between height growth and spring flushing in common beech (Fagus sylvatica L.), Annals of Forest Science, 68: 975-984. https://doi.org/10.1007/s13595-011-0103-1

Gordo O, Sanz JJ (2009) Long-term temporal changes of plant phenology in the Western Mediterranean. Global Change Biology, 15:, 1930-1948. https://doi.org/10.1111/j.1365-2486.2009.01851.x

Harter D, Nagy L, Backhaus S, Beierkuhnlein C, Fussi B, Huber G, Jentsch A, Konnert M, Thiel D, Kreyling J (2015) A Comparison of genetic diversity and phanotypic plasticity among European Beech (Fagus sylvatica L.) populations from Bulgaria and Germany under drought and temperature manipulation. Int. J. Plant Sci. 176 : 232-244. https://doi.org/10.1086/679349

Huber G, Cremer E, Petkova K, Konnert M (2011) Transfer of German beech prov enances to Bulgaria and vice versa, In: Proceedings of the 9th IUFRO International Beech Symposium 12-17 September, 2011, Dresden/Göttingen, Germany,pp. 96.

Huber G, Petkova K, Konnert M, Thiel D (2014) Transferversuche mit Buche (Fagus sylvatica) zur Prüfung der Angepasstheit im Klimawandel. Teil I: Anzucht 
unter stark unterschiedlichen Klimabedingungen, Allgemeine Forst- und Jagdzeitung, 185: 82-96.

IPCC (2013) Summary for policymakers. In: Climate Change 2013: The Physical Science Basis. Contribution of Working Group I to the Fifth Assessment Report of the Intergovernmental Panel on Climate Change (eds Stocker TF, Qin D, Plattner G-K, Tignor M, Allen SK, Boschung J, Nauels A, Xia Y, Bex V, Midgley PM), PP. 1535. Cambridge University Press, Cambridge, UK.

Jazbec A, Šegotić K, Ivanković M, Marjanovićand H, Perić S (2007) Ranking of European beech provenances in Croatia using statistical analysis and analytical hierarchy process, Forestry, 80: 151-162. https://doi.org/10.1093/forestry/cpm007

Jump AS, Hunt JM, Peñuelas J (2006) Rapid climate change-related growth decline at the southern range edge of Fagus sylvatica. Global Change Biology, 12: 2163-2174. https://doi.org/10.1111/j.1365-2486.2006.01250.x

Konnert M, Fady B, Gömöry D, A'Hara S, Wolter F, Ducci F, Koskela J, Bozzano M, Maaten T, Kowalczyk J (2015) European Forest Genetic Resources Programme (EUFORGEN). : Use and transfer of forest reproductive material in Europe in the context of climate change. European Forest Genetic Resources Programme (EUFORGEN), Bioversity International, Rome, Italy. xvi and 75 p.

Knutzen F (2016) Response of European beech to decreasing summer precipitation under global climate change, Dissertation zur Erlangung des mathematisch-naturwissenschaftlichen Doktorgrades „Doctor rerum naturalium" der Georg-August University, Göttingen, 201 pp.

Kreyling J, Thiel D, Nagy L, Jentsch A, Huber G, Konnert M, Beierkuhnlein C (2012) Late frost sensitivity of juvenile Fagus sylvatica L. differs between southern Germany and Bulgaria and depends on preceding air temperature. Eur J For Res 131: 717-725. https://doi.org/10.1007/s10342-011-0544-y

Mellert KH, Ewald J, Hornstein D, Dorado-Liñán I, Jantsch M, Taeger S, Zang C, Menzel A, Kölling C (2016) Climatic marginality: a new metric for the susceptibility of tree species to warming exemplified by Fagus sylvatica (L.) and Ellenberg's quotient. European Journal of Forest Research, 135 (1): 137-152. https://doi.org/10.1007/s10342-015-0924-9

Menzel A, Sparks TH, Estrella N et al. (2006) European phenological response to climate change matches the warming pattern. Global Change Biology, 12: 1969-1976. https://doi.org/10.1111/j.1365-2486.2006.01193.x

Nielsen CH, Jørgensen FV (2003) Phenology and diameter increment in seedlings of European beech (Fagus sylvatica L.) as affected by different soil water contents: variation between and wihin provenances, Forest Ecology and Management, 174: 233-249. https://doi.org/10.1016/s0378-1127(02)00042-7

Peñuelas J, Filella I, Comas P (2002) Changed plant and animal life cycles from 1952 to 2000 in the Mediterranean region. Global Change Biology, 8: 531 544. https://doi.org/10.1046/j.1365-2486.2002.00489.x

R Core Team (2014) R: A language and environment for statistical computing. R Foundation for Statistical Computing, Vienna, Austria. URL http://www.R-project.org/

Rita A, Gentilesca T, Ripullone F, Todaro L, Borghetti M (2014) Differential climate-growth relationships in Abies alba Mill. and Fagus sylvatica L. in Mediterranean mountain forests. Dendrochronologia, 32: 220-229. https://doi.org/10.1016/j.dendro.2014.04.001

Robson TM, Alía R, Bozic G, Clark J, Forstreuter M, Gömöry D, Liesebach M, Mertens $P$, Rasztovits $E$, Zitová $M$, von Wühlisch $G$ (2011) The timing of leaf flush in European beech (Fagus sylvatica L.) saplings. In: Genetic Resources of European Beech (Fagus sylvatica L.) for Sustainable Forestry Proceedings of the COST E52 Final Meeting.4-6 May 2010, Burgos, Spain, 61-80.

Robson TM, , Rasztovits E, Aphalo PJ, Alia R, Aranda I (2013) Flushing phenology and fitness of European beech (Fagus sylvatica L.) provenances from a trial in La Rioja, Spain, segregate according to their climate of origin. Agricultural and Forest Meteorology 180:76-85. https://doi.org/10.1016/j.agrformet.2013.05.008

Scharnweber T, Manthey M, Criegee C, Bauwe A, Schröder C, Wilmking M (2011) Drought matters - declining precipitation influences growth of Fagus sylvatica L. and Quercus robur L. in north-eastern Germany. Forest Ecology and Management 262: 947-961. https://doi.org/10.1016/j.foreco.2011.05.026

Thiel D, Kreyling J, Backhaus S, Beierkuhnlein C, Buhk C, Egen K, Huber G, Konnert M, Nagy L, Jentsch A (2014) Different reactions of central and marginal provenances of Fagus sylvatica to experimental drought. Eur J For Res 133: 247-260. https://doi.org/10.1007/s10342-013-0750-x

van der Maaten E (2012) Climate sensitivity of radial growth in European beech (Fagus sylvatica L.) at different aspects in southwestern Germany. Trees Structure and Function, 26 (3): 777-788. https://doi.org/10.1007/s00468-011-0645-8

Višnjić C, Dohrenbusch A (2004) Frostresistenz und Phänologie europäischer Buchenprovenienzen (Fagus sylvatica L.), Allg. Forst- und Jagdzeitung, .175 (6): 101-108.

von Wühlisch G, Krusche D, Muhs HJ (1995) Variation in temperature sum requirement for flushing of beech provenances. Silvae Genet. 44 (5-6): 343346.

Wickham H (2009) ggplot2: Elegant Graphics for Data Analysis. Springer-Verlag New York, 107 pp.

von Wühlisch G, LiesebachM, Muhs HJ, Stephan BR (1998) A network of international beech provenance trials. In: Turok J, Kremer A, de Vries SM (eds) First EUFORGEN meeting on social broadleaves : 23-25 October 1997, Bordeaux France. Rom: Euforgen Secretariat, pp 164-172. 